\title{
The Effect of Fly Ash Composition and Drying Time Concrete Brick in Density Test
}

\author{
Nurzal, Mastaryanto Perdana, Heru Pratama Putera \\ Institut Teknologi Padang, Mechanical Engineering Department, Padang, West Sumatra, Indonesia
}

\begin{abstract}
This study uses the fly ash (FA) from coal combustion power plant Sijantang Sawahlunto. By utilizing fly ash in concrete brick can reduce the negative impact on the environment, composition of fly ash in concrete brick at $0,5,10$, and $15 \mathrm{wt} . \%$ FA concrete brick added material (sand, cement and water as a binder). Influence of drying time 7, 14, 21, 28, and 35 days. Test specimen based on SNI 03-0349-1989, with size of 34 × 12 × $9 \mathrm{~cm}$. The results showed that the composition of $5 \mathrm{wt}$ \% fly ash with 28 days drying time was found to be the highest density with $2,230 \mathrm{gr} / \mathrm{cm} 3$, while the lowest density in the composition test was $15 \mathrm{wt} . \%$ fly ash with 35 days drying time with the density $1,946 \mathrm{gr} / \mathrm{cm} 3$. In this study, the density of normal concrete brick density with density 2,208-2,230 gr/cm3 and light concrete brick density of 2,000-1,946 gr/cm3, and also found a normal and light concrete brick category that is 2,022$2,053 \mathrm{gr} / \mathrm{cm} 3$.
\end{abstract}

\section{Introduction}

Housing and building development are increasing every year, along with population growth. One of the most common component of construction material used is concrete brick which is applied to wall in housing, building and fence. concrete brick is a concrete brick mold consisting of a mixture of cement, sand and water. concrete brick consists of two types of hollow concrete brick and solid concrete brick. concrete brick is one of the alternative substitutes of red concrete brick with the aim of reducing the cost of red concrete brick but has a quality that is not less good in red concrete brick. The use of concrete brick is considered more practical, economical and much in production with a relatively cheaper price variant [1]. Fly ash comes from coal combustion in steam power plants and an industrial waste that can cause negative impacts on the environment. Utilizing fly ash as raw material for a mix of concrete brick making is one solution to overcome it. Superior properties are owned by fy ash, such as: hardness, high strength and able to work well, so commonly applied in the field of construction, mechanical and chemical industry [2]. The purpose of this research is to know the composition of fly ash and the drying Time to density on concrete brick manufacturing and to determine the grouping based on the weight of the concrete brick.

\section{Teoritis and Methods}

Concrete brick is a material formed from a mixture of sand mixed with aggregate, cement and water to react perfectly. According to its shape, the concrete brick can be divided into two types, namely, hollow concrete brick and solid concrete brick. 28-day-old concrete brick has a physical weight of $12.128 \mathrm{~kg}$, density of $2.118 \mathrm{gr} / \mathrm{cm}^{3}$, water absorption of $12.876 \%$ and compressive strength of $1.97 \mathrm{MPa}$ [3]. The effect of the use of fly ash on compressive strength and water absorption in mortar, obtained: the addition of fly ash with a certain percentage of the weight of the cement turned out to increase the compressive strength of mortar. The increase of compressive strength occurred at percentage of fly ash by $10 \%$ with compressive strength at age 56 days at $100,72 \mathrm{gr} / \mathrm{cm}^{2}$ and projection of characteristic compressive strength at age 28 day equal to 66,69 $\mathrm{gr} / \mathrm{cm}^{2}$, at percentage fly ash of $20 \%$ with a compressive strength at age 56 days of $93.96 \mathrm{gr} / \mathrm{cm}^{2}$ and a projection of a characteristic compressive strength at age 28 days of $62.16 \mathrm{gr} / \mathrm{cm}^{2}$, at a percentage of $\mathrm{fly}$ ash by $30 \%$ with compressive strength at age 56 days of $83,41 \mathrm{gr} / \mathrm{cm}^{2}$ and projection of characteristic compressive strength at age 28 day was $55,17 \mathrm{gr} / \mathrm{cm}^{2}$ and at percentage of fly ash $40 \%$ with compressive strength at age 56 day $70,12 \mathrm{gr} / \mathrm{cm}^{2}$ and projection of compressive strength characteristic at 28 days age of $46.42 \mathrm{gr} / \mathrm{cm}^{2}$. While on mortar withcontent, the fly ash $0 \%$ compressive strength of the age of 56 days was 59.89 $\mathrm{gr} / \mathrm{cm}^{2}$ and the projection of compressive strength was 28 days at $42,34 \mathrm{gr} / \mathrm{cm}^{2}$ [4]. The mechanical properties of the concrete brick mixed with fly ash show the addition 5\% fly ash resulting in a compressive strength of $20.76 \mathrm{MPa}, 10 \%$ fly ash the result of compression strength $26.00 \mathrm{MPa}, 15 \%$ fly ash obtained compression strength $22.40 \mathrm{MPa}$, while the normal concrete brick is without fly ash obtained the compressive strength 16.46

\footnotetext{
*Corresponding author: nurzall@gmail.com
} 
$\mathrm{MPa}$ [5]. Factors affecting the quality of concrete brick: a good concrete brick has a flat surface and perpendicular to each other and has a high compressive strength. Factors affecting the quality of the concrete brick are dependent on water cement factor, age, density, shape and rock structure and aggregate size on the concrete brick. Concrete brick is classified into 2 groups namely normal concrete brick and lightweight concrete brick. The normal concrete brick is classified as a concrete brick which has density of about $2.200-$ $2.400 \mathrm{gr} / \mathrm{cm}^{3}$, while for light concrete is a concrete brick that has density $<2.000 \mathrm{gr} / \mathrm{cm}^{3}$ or lower and supported with maximum absorption $25 \%$ according to SNI $03-$ 0349-1989 with a maximum compressive strength of 0.3 - $40 \mathrm{MPa}[6]$.

Table 1. Concrete brick Quality [7]

\begin{tabular}{|c|c|c|c|c|c|c|}
\hline \multirow[t]{2}{*}{ NO. } & \multirow{2}{*}{$\begin{array}{c}\text { Quality } \\
\text { Requirement }\end{array}$} & \multirow[t]{2}{*}{ Unit } & \multicolumn{4}{|c|}{$\begin{array}{c}\text { Solid concrete brick } \\
\text { Quality }\end{array}$} \\
\hline & & & I & II & III & IV \\
\hline 1 & $\begin{array}{l}\text { Bruto } \\
\text { compressive } \\
\text { strength and } \\
\text { minimum } \\
\text { average }\end{array}$ & $\mathrm{Kg} / \mathrm{cm}^{2}$ & 100 & 70 & 40 & 25 \\
\hline 2 & $\begin{array}{l}\text { Bruto } \\
\text { compressive } \\
\text { strength of } \\
\text { each specimen } \\
\text { is minimum }\end{array}$ & $\mathrm{Kg} / \mathrm{cm}^{2}$ & 90 & 65 & 35 & 21 \\
\hline 3 & $\begin{array}{l}\text { Maximum } \\
\text { water } \\
\text { absorption }\end{array}$ & $\%$ & 25 & 35 & - & - \\
\hline
\end{tabular}

Table 2. Terms of Standard Size and Concrete Brick Size Tolerance [7]

\begin{tabular}{|c|c|c|c|c|}
\hline $\begin{array}{c}\text { FA } \\
\text { Composition } \\
\text { (wt.\%) }\end{array}$ & $\begin{array}{c}\text { Cement } \\
(\mathrm{kg})\end{array}$ & $\begin{array}{c}\text { Sand (Fine } \\
\text { Sand }+\end{array}$ & $\begin{array}{c}\text { Fly } \\
\text { Ash } \\
\text { Aggregate) } \\
(\mathrm{kg})\end{array}$ & Water \\
\hline 0 & 30 & 463 & 0 & 30 \\
\hline 5 & 30 & 439,85 & 23,49 & 45 \\
\hline 10 & 30 & 416,7 & 44,67 & 54 \\
\hline 15 & 30 & 393,55 & 63,53 & 63 \\
\hline
\end{tabular}

Concrete brick has the following advantages

1. Concrete brick has a larger dimension of red brick so that the installation time is faster without having to be soaked before installation and installation cost is cheaper.

2. Making it easier without requiring burning process.

3. No need to be plastered if the workmanship is neat.

4. Can be made perforated for air ventilation and the possibility of water seepage is very small because it is watertight.

Disadvantages:

1. Easy to crack the hair on the wall.

2. Easy to be perforated and easily broken because there are holes on the inner side.
3. Less good for heat and sound insulation.

\section{Composition Concrete brick}

The composition for the manufacture of concrete brick work is as follows:

Table 3. Concrete brick composition for 70 spesimens

\begin{tabular}{|c|c|c|c|c|c|c|}
\hline \multirow{2}{*}{$\begin{array}{l}\mathrm{N} \\
\mathrm{o}\end{array}$} & \multirow[t]{2}{*}{ Type } & \multicolumn{3}{|c|}{ dimensions (mm) } & \multicolumn{2}{|c|}{$\begin{array}{l}\text { Minimum wall } \\
\text { thickness } \\
(\mathrm{mm})\end{array}$} \\
\hline & & $\begin{array}{c}\text { Lengt } \\
\mathrm{h}\end{array}$ & $\begin{array}{c}\text { Widt } \\
\mathrm{h}\end{array}$ & $\begin{array}{c}\text { Heigh } \\
\mathrm{t}\end{array}$ & $\begin{array}{c}\text { outsid } \\
\mathrm{e}\end{array}$ & $\begin{array}{c}\text { insid } \\
\mathrm{e}\end{array}$ \\
\hline 1 & Solid & $\begin{array}{c}390 \pm \\
5\end{array}$ & $\begin{array}{c}90 \pm \\
2 \\
\end{array}$ & $\begin{array}{c}100 \pm \\
2 \\
\end{array}$ & - & - \\
\hline \multirow[t]{2}{*}{2} & $\begin{array}{l}\text { Hollow } \\
\text { : Small }\end{array}$ & $\begin{array}{c}390 \pm \\
5\end{array}$ & $\begin{array}{l}190 \\
\pm 5\end{array}$ & $\begin{array}{c}100 \pm \\
2\end{array}$ & 20 & 15 \\
\hline & Large & $\begin{array}{c}390 \pm \\
5\end{array}$ & $\begin{array}{l}190 \\
\pm 5\end{array}$ & $\begin{array}{c}200 \pm \\
3\end{array}$ & 25 & 20 \\
\hline
\end{tabular}

The production of a concrete brick wth composition 0 wt. $\%$ fly ash needed $0.42 \mathrm{~kg}$ of cement and $6.61 \mathrm{~kg}$ sand. For 5 wt.\% fly ash used $0.004 \mathrm{~kg}$ cement, $6.23 \mathrm{~kg}$ sand and $0.38 \mathrm{~kg}$ fly ash.
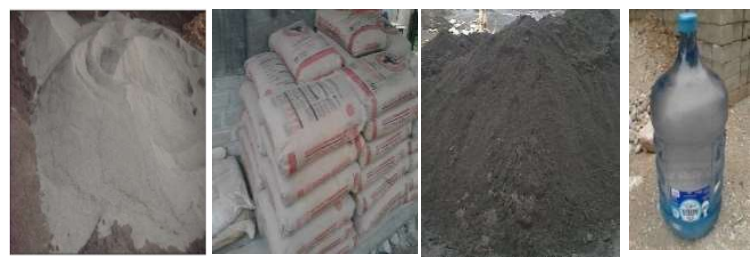

Fig.1: Material used: (a) Fly ash, (b) Cement, (c) sand, and (d) Mineral Water

\section{Shape and Size Specimens}

Based on SNI SNI 03-0349-1989, Specimens were produced in the form of rectangular bar (length, $\mathrm{L}=34$ $\mathrm{cm}$, width, $\mathrm{B}=12 \mathrm{~cm}$, thickness, $\mathrm{W}=9 \mathrm{~cm}$ ).

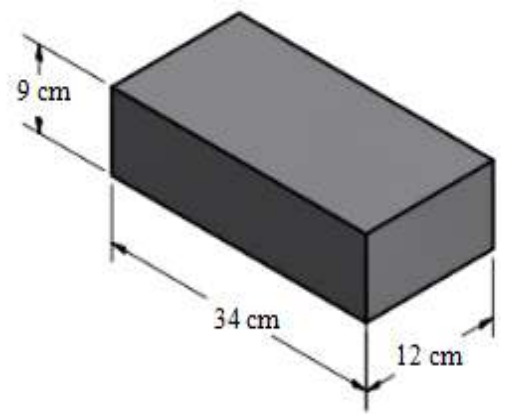

Fig.2: Shape and size of Concrete brick

\section{Compaction Process}

Base on the Composition of Materials concrete brick (Table3). The materials are manually mixing to homogeneous and flush with mineral water until it forms a paste after that into a mold concrete brick. The concrete brick compaction is done manually, then concrete brick was placed above the board and let it harden for 1 night and not exposed to direct sunlight to 
avoid cracking, after that concrete brick is dried in for 7 , $14,21,28$, and 35 days.

\section{Density Test}

Measureing density is used Archimedes method:

Density $=\frac{\mathrm{W}_{\mathrm{u}}}{\mathrm{W}_{\mathrm{u}}-\mathrm{W}_{\mathrm{f}}} \cdot \rho_{\text {air }}$

Where:

$$
\begin{aligned}
& \rho_{\text {water }}=\text { density of water }=1 \mathrm{~g} / \mathrm{cm}^{3} \\
& \mathrm{~W}_{\mathrm{u}}=\text { weight in air }\left(\mathrm{g} / \mathrm{cm}^{3}\right) \\
& \mathrm{W}_{\mathrm{f}} \quad=\text { weight in water }\left(\mathrm{g} / \mathrm{cm}^{3}\right)
\end{aligned}
$$

\section{Results and Discussion}

The 0 wt.\% fly ash, the longer the drying time, the density increases, due to the chemical reaction between cement and water (hydration) which causes the brick to become hard after some time (water absorption increases, and compressive strength drops).

Tabel 4. Average Density

\begin{tabular}{|c|c|c|c|c|c|}
\hline \multirow{2}{*}{$\begin{array}{c}\text { Fly Ash } \\
\begin{array}{c}\text { Composition } \\
\text { (wt.\%) }\end{array}\end{array}$} & $\begin{array}{c}7 \\
\text { Days }\end{array}$ & $\begin{array}{c}14 \\
\text { Days }\end{array}$ & $\begin{array}{c}21 \\
\text { Days }\end{array}$ & $\begin{array}{c}28 \\
\text { Days }\end{array}$ & $\begin{array}{c}35 \\
\text { Days }\end{array}$ \\
\hline 0 & 1.962 & 1.970 & 1.983 & 1.993 & 2.000 \\
\hline 5 & 1.978 & 2.208 & 2.220 & 2.230 & 1.953 \\
\hline 10 & 1.985 & 1.986 & 2.053 & 2.001 & 1.948 \\
\hline 15 & 1.992 & 1.984 & 1.975 & 1.967 & 1.946 \\
\hline
\end{tabular}

Drying time of 7, 14, 21 days increased density value and reached maximum density value in 28 days drying time of $2,230 \mathrm{gr} / \mathrm{cm}^{3}$, this happened at composition 5 wt.\% fly ash and density value of brick decreased until $1,953 \mathrm{gr} / \mathrm{cm}^{3}$ at drying 35 days. This result is similar to the research done by Tjokrodimulyo, 1995: on the addition of fly ash as much as $5 \mathrm{wt} \%$ fly ash and the duration of drying of 28 days cement will have hardness reaching the maximum value can be known also from the bright cement color than before and also proven also from research [8].

The density increased from 1.985 to $2.053 \mathrm{gr} / \mathrm{cm}^{3}$ on the drying time of 7, 14 and 21 days after that decreased density composition $10 \mathrm{wt} \%$ fly ash. All densities in this composition are light brick categories.

The composition of 15 wt.\% fly ash increased density value at 7 days drying time, which is the same because the water content is still high so the density value increases. In the old variation of drying 14 days with the variation of the composition there is an increase in density value at $5 \mathrm{wt} . \%$ composition and there is a decrease in density value in the composition of 10 and 15 wt.\% fly ash This is caused by the hydration of cement and fly ash which causes heat so that bubbles arise produce gas to produce pores that make concrete brick progressively lighter. In the long variation of drying of 21 days, 28 days and 35 days the same increase of density value in 5 wt.\% fly ash and degradation of 10 and $15 \mathrm{wt} \%$ fly ash value. This is due to the decreasing density due to the grain factor of the sample, the pore, and the composition of the material itself. Aggregate items may be less strong because of two things that are composed of weak materials or composed of strong but not good particles in the binder [9].

The pores on the concrete brick are caused by fly ash particle size smaller than the size of the cement particles will cover the pores that cause the lighter concrete brick. In the chart obtained density value $1.946-2.230 \mathrm{gr} / \mathrm{cm}^{3}$. The density values of $1.946-2.000 \mathrm{gr} / \mathrm{cm}^{3}$ include the light concrete brick category and the density value of $2.200-2.230 \mathrm{gr} / \mathrm{cm}^{3}$ the normal concrete brick category while the density value $2.001-2.053 \mathrm{gr} / \mathrm{cm}^{3}$ was in the category between light concrete brick and concrete brick normal.

\section{Conclusion}

The results of the research can be concluded as follows:

1. the composition of $5 \mathrm{wt} . \%$ fly ash with 28 days drying time was found to be the highest density with $2,230 \mathrm{gr} / \mathrm{cm}^{3}$, while the lowest density in the composition test was 15 wt. $\%$ fly ash with 35 days drying time with the density 1,946 $\mathrm{gr} / \mathrm{cm}^{3}$.

2. The density of normal concrete brick density with density 2,208-2,230 $\mathrm{gr} / \mathrm{cm}^{3}$ and light concrete brick density of 2,000-1,946 gr/ $\mathrm{cm}^{3}$, and also found a normal and light concrete brick category that is $2,022-2,053 \mathrm{gr} / \mathrm{cm}^{3}$.

\section{References}

1. Sagel, Ing R et al (1994). Guidelines for Concrete Work. Erlangga Publishers, Jakarta.

2. Boccacini, AK, (1995) Glass-Ceramics from Filter Dust from Waste Incinerators. Cramics International Journal, 21, 231-235.

3. Darmono (2009) Penerapan Teknologi Produksi Bahan Bangunan Berbahan Pasir Bagi Korban Gempa Di Kulonprogo Serta Analisis Mutu Dan Ekonominya. Fakultas Teknik Universitas Negeri Yogyakarta

4. Andoyo (2006). The Influence of Fly Ash's Uses of Pressure and Water Absorption on Mortar. Unpublished Undergraduade Thesis, Semarang State University.

5. Siagian, Henok and Dermawan Agus (2011) Tests of Concrete brick Mixed Mechanics of Fly Ashes

6. Neville, A.M and Broks, JJ (1987) 'Concrete Technology.' Longman Scientific \& Technical, London

7. Indonesian National Standard (SNI) 03-0349-1989 Concrete Concrete brick for Couple Wall.

8. Tjokrodimuljo, Kardiyono (1995) 'Concrete Technology. Yogyakarta

9. Mulyono, T., (2008) Concrete Technology, Andi Publisher, Yogyakarta. Indonesian Concrete Regulation (PBI, 1971) About Aggregates 


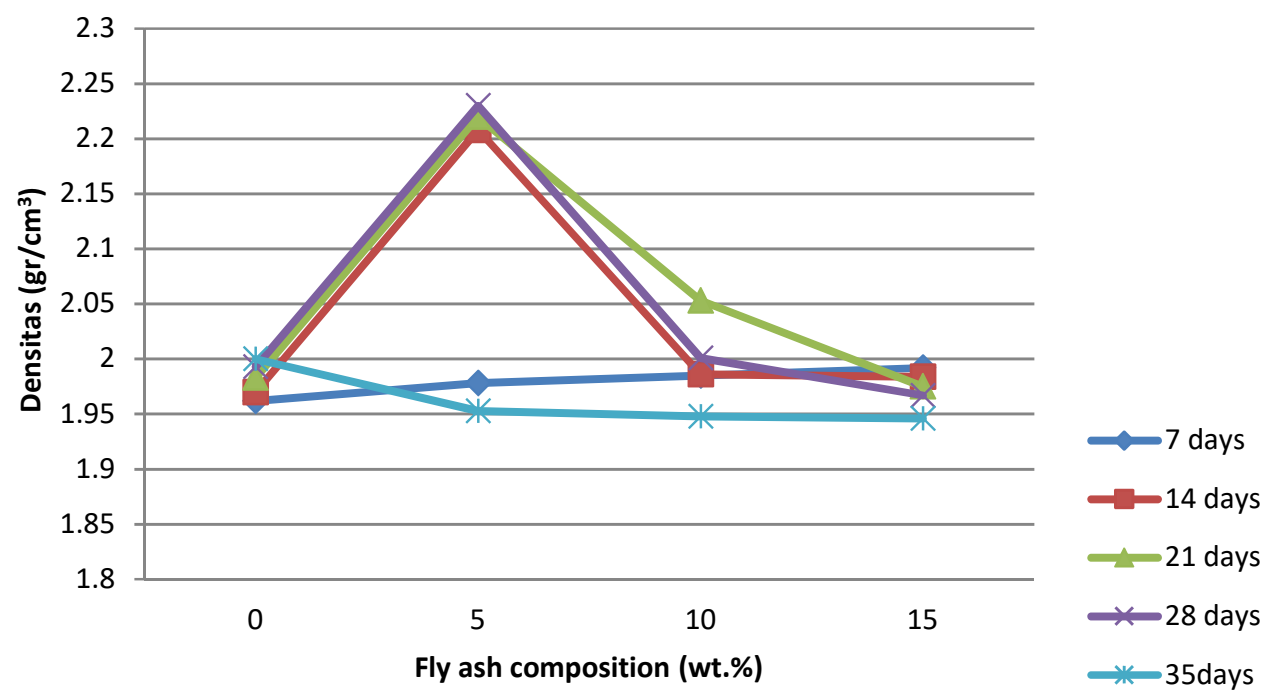

Fig. 3: Relationship fly ash composition with density 